\title{
Growth differences in larval plaice Pleuronectes platessa in the Southern Bight of the North Sea as indicated by otolith increments and RNA/DNA ratios
}

\author{
F. Hovenkamp \\ Netherlands Institute for Sea Research, PO Box 59, 1790 AB Den Burg, The Netherlands
}

\begin{abstract}
Somatic and otolith growth of larval plaice Pleuronectes platessa L. was studied under field and experimental conditions. Rearing experiments at 6 and $9^{\circ} \mathrm{C}$ demonstrated a relation between somatic and ofolith growth, and a larger size-at-stage for fast growing larvae. In the field, 2 groups of larval plaice were caught at dates 2 wk apart in the southern North Sea in March 1988, and growth was examined using 4 methods: size-at-age, size-at-developmental stage, otolith increment widths, and RNA/DNA ratios. All methods yielded the same result. Larvae captured on 22 March had been growing faster then larvae caught on 8-9 March. Larvae from 22 March were larger at the same age, and had attained a larger size at the same developmental stage. Slow growth led to relatively large otoliths. Analysis of otolith increments showed these growth differences to be of recent origin, a conclusion that is supported by higher RNA/DNA ratios of the late group. Temperature differences were too small to explain this difference, and temporary starvation or food limitation may have occurred.
\end{abstract}

\section{INTRODUCTION}

The number of papers on larval fish research invoking microstructural examination of otoliths has increased rapidly during the last few years (see reviews by Campana \& Neilson 1985, and Jones 1986). Otoliths are calcareous objects found in the labyrinth system of fishes. Most of the research has focused on the largest pair of otoliths, usually the sagitta, in which a pattern of concentric rings is normally found. The periodicity of these increments, each consisting of 2 zones with different chemical and optical properties, has been shown to be daily for most species examined (Pannella 1980, Campana \& Neilson 1985, Jones 1986). The otoliths thus provide us with an accurate indication of age, which greatly facilitates the study of larval growth in the field.

Another way of using otoliths for growth studies is to use the width of the increments as an indication of somatic growth (Method 1981, Neilson \& Geen 1982, Wilson \& Larkin 1982, Volk et al. 1984, Govoni et al. 1985. Penney \& Evans 1985, Barkman \& Bengtson 1987. Hovenkamp 1989). This method finds its justification in a direct relation between larval size and otolith size, and is very appealing, because it permits backcalculation of the growth history of the larvae. This is not a new method to fisheries biologists, and it has been used with annual marks in scales since the beginning of this century (Lea 1910, Lee 1912). The technique is routinely applied on annual marks in otoliths (Ricker 1969), but for analysis of daily growth increments, this approach has recently been criticized by several authors (Mosegaard \& Titus 1987, Mosegaard et al. 1988, Secor \& Dean 1989), because: (1) somatic growth can be zero or negative, while otolith growth cannot be negative and will escape detection when zero; (2) otolith growth may be more a function of temperature than of somatic growth; and (3) otolith growth has been shown to proceed at least for some time when larvae are starved (Neilson \& Geen 1982, McGurk 1984, Bailey \& Stehr 1988, Karakiri \& Westernhagen 1989), though it will come to a halt if starvation lasts long enough (Method \& Kramer 1979. Geffen 1982).

Otolith growth may thus be more a function of metabolic activity than of somatic growth. A corollary of these arguments is that otoliths of slow growing larvae will be relatively larger than otoliths of fast 
growing larvae, which has been reported by several authors (Marshall \& Parker 1982, Post \& Prankevicius 1987, Mosegaard et al. 1988, Reznick et al. 1989, Secor \& Dean 1989).

The relation between fish size and otolith size may thus be complicated by several factors, such as food level, temperature, or disruptions of somatic growth. This does not mean that the results of growth studies based on increment widths are invalidated, however. Several authors report similar growth obtained from back calculation from increment widths and length frequency modes (Barkman \& Bengtson 1987) or from increment widths and length-at-age data (Wilson \& Larkin 1982, Penney \& Evans 1985). But, in most field studies only length-specific growth rates are presented. When only length-at-age data are used, it is impossible to identify at which stage of life possible differences in size occur. Small differences in size may not be important at a later stage, but they may have been important at the time when these differences were generated, when they were relatively much larger. It could be important, for instance, to know whether intervals of food shortage caused such differences and whether these periods can later be traced in the otoliths. Method (1981) and Govoni et al. (1985) did this by comparing growth rates with the width of the most recently formed increments. A more sensitive method to determine whether short-term starvation is really taking place is by means of analysis of RNA/DNA ratios. The RNA/DNA ratio reflects the nutritional state of fish larvae during the last few days prior to sampling (Buckley 1984).

In this study I will present results of a field study on growth of larval plaice Pleuronectes platessa L. Plaice larvae were sampled on 2 dates at 5 locations in the Southern Bight of the North Sea, as a part of a larger study on growth differences within and between years. For more information about the early life history of plaice the reader is referred to Bannister et al. (1974) and Harding et al. (1978). Differences in growth are based on the size-age relationship, size-stage relationship, analysis of RNA/DNA ratios, and otolith increment widths. The results will be supported by otolith and size data from laboratory-reared larvae of known age, and the effects of temperature will be discussed.

\section{MATERIAL AND METHODS}

Laboratory experiments. Experiments were conducted in winter and spring 1987 Ripe plaice were stripped to obtain eggs, which were artificially fertiljzed and reared in plastic buckets at a temperature of 6 to $7^{\circ} \mathrm{C}$. After hatching, the larvae were transferred to plastic containers (ca 60 1) at temperatures of 3,6 and $9^{\circ} \mathrm{C}$. Larvae were fed with live Artemia nauplii and, when available, natural zooplankton (size 200 to 500 um). Samples of 4 to 5 larvae were taken from each container at 4 to $5 \mathrm{~d}$ intervals, depending on the numbers of larvae present, up to an age of $28 \mathrm{~d}$. After that time the remaining larvae were collected after metamorphosis. Growth at $3^{\circ} \mathrm{C}$ was extremely slow, and mortality high, so only larvae from 6 and $9^{\circ} \mathrm{C}$ were used for further analysis. Exponential growth curves were fitted to the size-age relationships of the larvae. Average daily somatic growth of the larvae was calculated as:

(size - estimated size at hatching)/age and average daily otolith growth was calculated as:

(otolith radius - estimated otolith radius at hatching)/age.

Larvae hatched normally within a period of 3 to $5 \mathrm{~d}$; the date of hatching was chosen as the date at which ca $50 \%$ of the larvae had hatched. Newly hatched plaice were ca $7 \mathrm{~mm}$ long, with a height of ca $0.3 \mathrm{~mm}$, and an otolith radius of ca $10 \mu \mathrm{m}$. Because of relatively large aging errors in recently hatched larvae, only larvae older than $10 \mathrm{~d}$ were used in calculating somatic and otolith growth. Otoliths of laboratory-reared larvae showed a less regular increment pattern than otoliths collected from fish in the field, as well as a reduced contrast between light and dark zones thus making increments difficult to count. A daily deposition of increments has been demonstrated for plaice larvae (Karakiri \& Westernhagen 1988).

Sampling at sea. At sea, larvae were sampled on several positions in the Southern Bight of the North Sea in 1988 (Fig. 1) on 8-9 March and March 22, with double oblique hauls of an Isaacs-Kidd mid-watertrawl. Details of sampling locations and preservation methads are given in Table 1. A subsample of 5 larvae

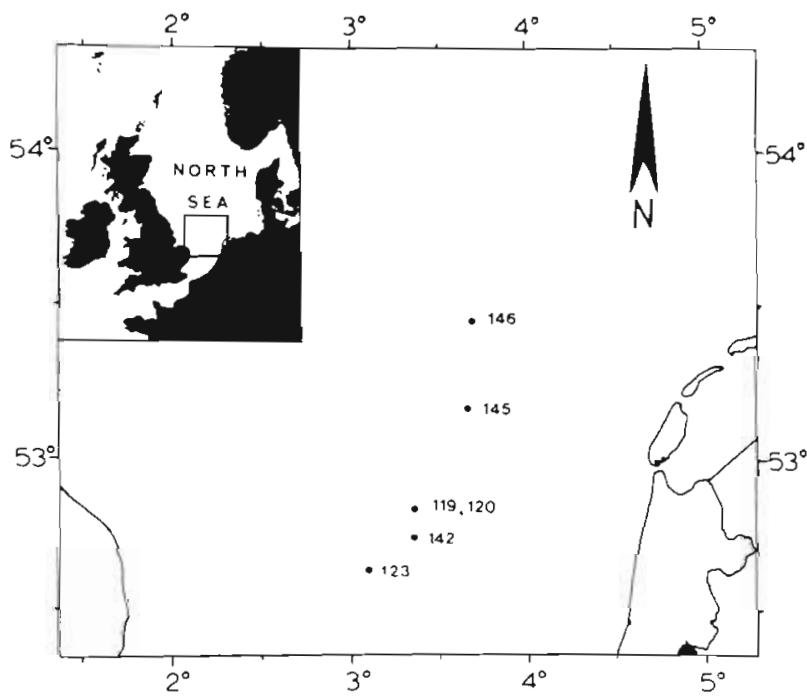

Fig. 1. The North Sea showing location of sampling stations 
Table 1 Collection of information and fixation methods. Alc.; alcohol; Form.; formaldehyde

\begin{tabular}{|c|c|c|c|c|c|c|c|}
\hline Station & $\begin{array}{c}\text { Date } \\
(1988)\end{array}$ & Latitude & Longitude & $\begin{array}{l}\text { Temp. } \\
\left({ }^{\circ} \mathrm{C}\right)\end{array}$ & Fixative & Purpose & $\mathrm{N}$ \\
\hline 119 & Mar 8 & $52^{\circ} 50^{\prime} 57$ & $3^{\circ} 22^{\prime} 54$ & 6.1 & Alc. $96 \%$ & Otoliths & 66 \\
\hline 119 & Mar 8 & $52^{\circ} 20^{\prime} 57$ & $3^{\circ} 22^{\prime} 54$ & 6.1 & Nitrogen & RNA/DNA & 22 \\
\hline 120 & Mar 8 & $52^{\circ} 50^{\prime} 57$ & $3^{\circ} 22^{\prime} 54$ & 6.1 & Form. $4 \%$ & Size-weight & 72 \\
\hline 123 & Mar 9 & $52^{\circ} 39^{\prime} 08$ & $3^{\circ} 07^{\prime} 69$ & 6.4 & Nitrogen & RNA/DNA & 4 \\
\hline 142 & $\operatorname{Mar} 22$ & $52^{\circ} 45^{\prime} 25$ & $3^{\circ} 23^{\prime} 92$ & 7.0 & Nitrogen & RNA/DNA & 11 \\
\hline 145 & Mar 22 & $53^{\circ} 10^{\prime} 36$ & $3^{\circ} 42^{\prime} 49$ & 6.8 & Alc. $96 \%$ & Otoliths & 33 \\
\hline 146 & Mar 22 & $53^{\circ} 28^{\prime} 19$ & $3^{\circ} 49^{\prime} 12$ & 6.4 & Form. $4 \%$ & Size-weight & 84 \\
\hline
\end{tabular}

per stage was taken from Station 145, while at the other stations all larvae were used. Larvae used for determination of size-weight relationships were preserved in formaldehyde, because this causes less change in weight than alcohol fixation (Bailey 1982). Samples were sorted on board, weather permitting, or in the laboratory. Live larvae were taken on board for RNA DNA analysis and stored as quick as possible in liquid nitrogen $\left(-196^{\circ} \mathrm{C}\right)$. Temperatures were measured from surface bucket readings.

Staging and measuring. Stages of larvae were noted according to the terminology of Ryland (1966), but Stages $2 a$ and $2 a^{\prime}, 2 b$ and $2 b^{\prime}, 3 a$ and $3 a^{\prime}$ and $3 b$ and $3 b^{\prime}$ were taken together as $2 \mathrm{a}, 2 \mathrm{~b}, 3 \mathrm{a}$ and $3 \mathrm{~b}$. Standard length and the height of the myotomal musculature at the anus were measured under a dissecting microscope with an ocular micrometer. No allowances have been made for shrinkage, or loss of weight after fixation, and shrinkage was assumed to be the same for alcohol and formaldehyde fixation. The amount of shrinkage after preservation in liquid nitrogen is not known.

Otolith preparation and examination. Sagittal otoliths were removed under a dissecting microscope, mounted in clear nail polish (sulcus side down) and photographed on high contrast black-and-white film using transmitted light at magnifications of ca 300 to $1600 \times$. All measurements were taken from projections of the negatives. Otolith increments were counted and the position of the first clearly visible increment and each subsequent tenth increment relative to the nucleus was measured, as well as the radius along the transect of counting and the minimum and maximum diameter. The transect of reading was chosen where the increments were most clearly visible. Three counts were made and if counts differed by more than 3 (absolutely) or $10 \%$ of the mean count the otoliths were excluded from for further analysis. The otoliths are not always circular and because the midpoint may be located asymmetrically, all measured distances were standardized to a mean otolith radius, which was taken as the mean of the smallest and largest otolith diameter divided by 2 . Average increment widths were calculated for increments 1 to 10,11 to 20 , and 21 to 30 . No otoliths with 40 or more increments were found. To obtain an impression of the most recent otolith growth, the sum of the width of the last 5 complete increments was measured.

Size-weight relationships. The relationship between larval dry weight and otolith size has been determined by a direct and indirect method. Indirectly, the size of the larvae is related to the dry weight and to the otolith diameter, after which both equations are combined, by substitution, to yield an equation between dry weight and otolith diameter. To provide a direct relationship, a number of larvae from Stations 120 and 146 were staged and measured as indicated, and dried for ca $40 \mathrm{~h}$ at $70^{\circ} \mathrm{C}$, after which they were weighed with a precision of $0.01 \mathrm{mg}$. After weighing the larvae were immersed in $96 \%$ alcohol and the otoliths were inspected. In a number of cases, otoliths were affected either by drying or by the formaldehyde fixation, or both, but in $55 \%$ of the larvae, otoliths appeared undamaged, and they were measured and used for further analysis as described above.

RNA/DNA ratios. RNA/DNA ratios were measured as described by Clemmesen (1988). The concentration of RNA and DNA together is determined fluorometrically after enhancement of fluorescence with ethydidium bromide. The concentration of DNA is determined in the same way using bisbenzimidazol (Hoechst 33258), after which the concentration of RNA can be calculated. To compare values with those of starving larvae, late larval stages (Stage $3 c$ to 5) migrating into the tidal areas were collected, and starved for periods ranging from 0 to $5 \mathrm{wk}$ at $6^{\circ} \mathrm{C}$, after which they were stored in liquid nitrogen until analysis.

Statistical procedures. Size-weight relationships were calculated using normal linear regressions. To provide the most accurate regression equation between larval size and otolith diameter all data available from 1988 were used which includes data not further used in this study, but presented in Fig. 2.

The width of the last 5 increments cannot be compared directly with each other, as increment width is (at least partly) dependent on otolith size. The width of the last 5 increments was linearly related to the logarithm 
of the otolith diameter at the time of formation of the first of these increments. When this width is larger than expected, according this relation, the regression residuals will be positive, and otolith growth has been more than average. When it is smaller than expected, otolith growth has been less than average, and the residuals will be negative. In this way the residuals can be used as an index of recent otolith growth.

Comparisons between linear models were made by standard analysis of covariance (ANCOVA) procedures. Comparisons between exponential models were made by first linearizing the model and then applying ANCOVA procedures. Differences of size between groups were tested using a 2-factor analysis of variance (ANOVA) with groups or temperature and stages as factors. Differences between means were calculated using t-tests, or Mann-Whitney U-tests, in case of small sample sizes. All significances are calculated for $\alpha=$ 0.05 .

\section{RESULTS}

\section{Size-weight relationships}

The best linear relationships between size of the larvae, otolith diameter and dry weight were found using the product of length (L) and squared height $\left(\mathrm{H}^{2}\right)$ as a measure of size. A good linear relation is found between the size of the fish and otolith diameter:

$\mathrm{L} \times \mathrm{H}^{2}=-135.8+2.939 \cdot \mathrm{OD}, \mathrm{r}=0.891, \mathrm{~N}=340$

(1) (Fig. 2)

Dry weight is linearly related to $\mathrm{L} \times \mathrm{H}^{2}$ according to:

$\mathrm{DW}=18.81+1.3985 \cdot \mathrm{L} \times \mathrm{H}^{2}, \mathrm{r}=0.971, \mathrm{~N}=156$

(2) (Fig. 3)

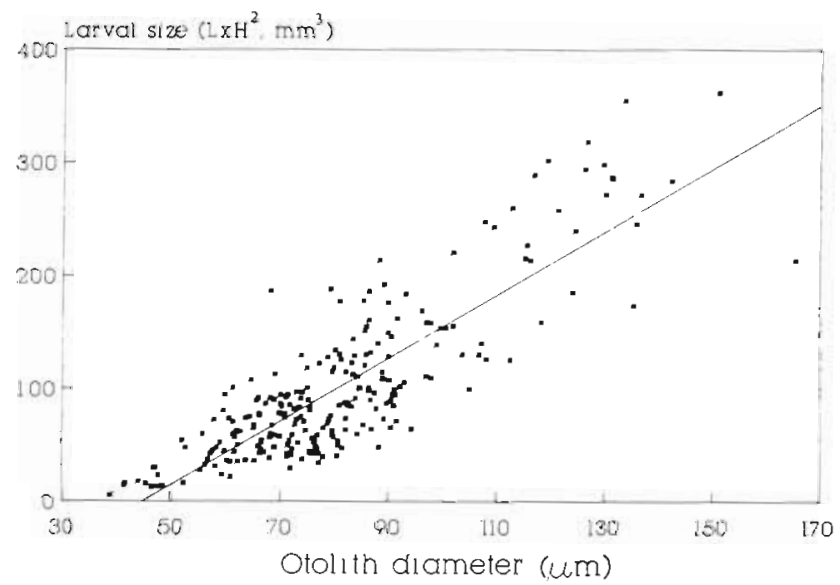

Fig. 2. Pleuronectes platessa. Regression of larval size $\left(\mathrm{L} \times \mathrm{H}^{2}\right)$ on otolith diameter (OD). $\mathrm{L} \times \mathrm{H}^{2}=-135.8+2.939 \mathrm{OD}$. $\mathrm{r}=0.89, \mathrm{~N}=340$

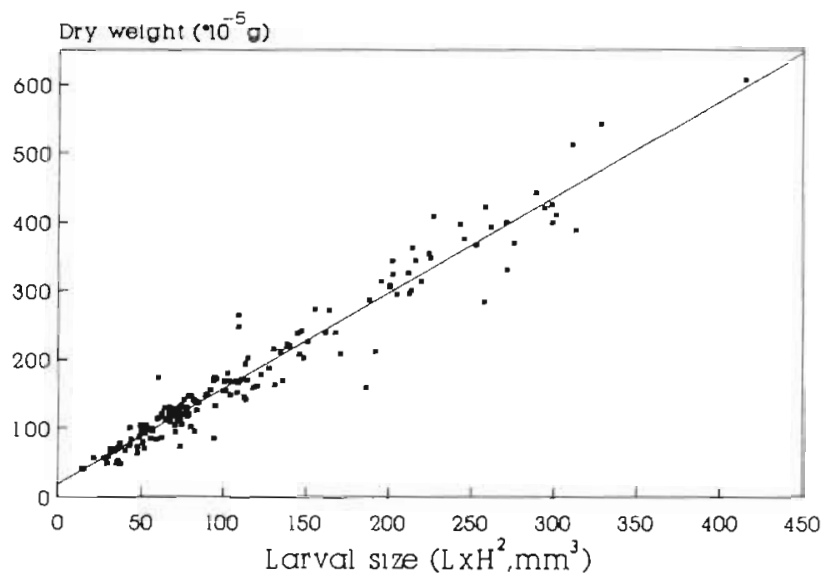

Fig. 3. Pleuronectes platessa. Regression of dry weight (DW) on larval size $\left(\mathrm{L} \times \mathrm{H}^{2}\right)$. DW $=18.81+1.395 \mathrm{~L} \times \mathrm{H}^{2}, \mathrm{r}=0.97$,

$$
N=1.56
$$

This leads to a calculated relation between dry weight and otolith diameter:

$\mathrm{DW}=-170.58+4.009 \cdot \mathrm{OD}$

The observed relation between dry weight and otolith diameter was:

$\mathrm{DW}=-149.52+3.990 \quad \mathrm{OD}_{1} \mathrm{I}=0.888, \mathrm{~N}=78$

(4) (Fig. 4)

The calculated line falls within the $5 \%$ confidence limits of the observed regression, and is thus in reasonably good agreement with the observed values. Thus, either a direct or indirect method can be used to relate the dry weight of the larvae to the otolith diameter.

\section{Laboratory experiments}

Larval size is plotted against otolith diameter for both temperatures in Fig. 5. Although the otoliths from lar-

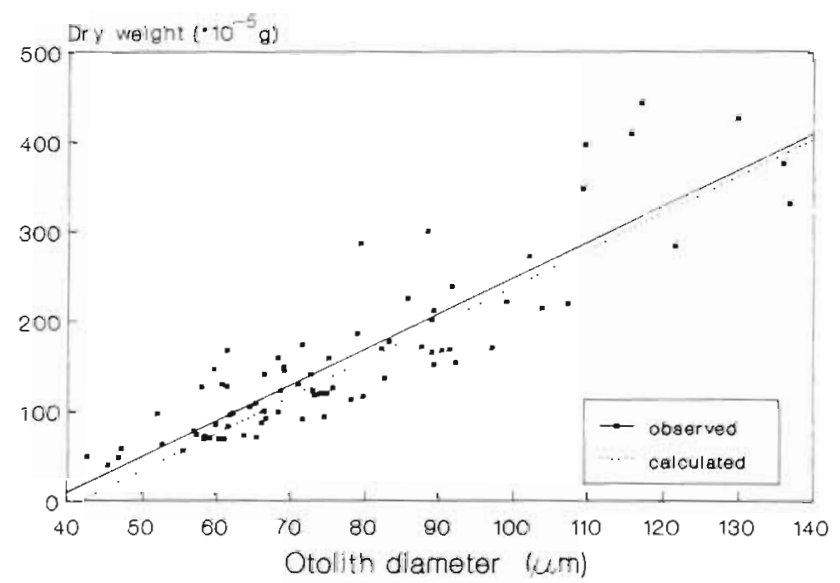

Fig. 4. Pleuronectes platessa. Regression of dry weight (DW) on otolith diameter (OD). DW $=-149+3.99 \cdot$ OD, $r=0.89$,

$$
N=78
$$




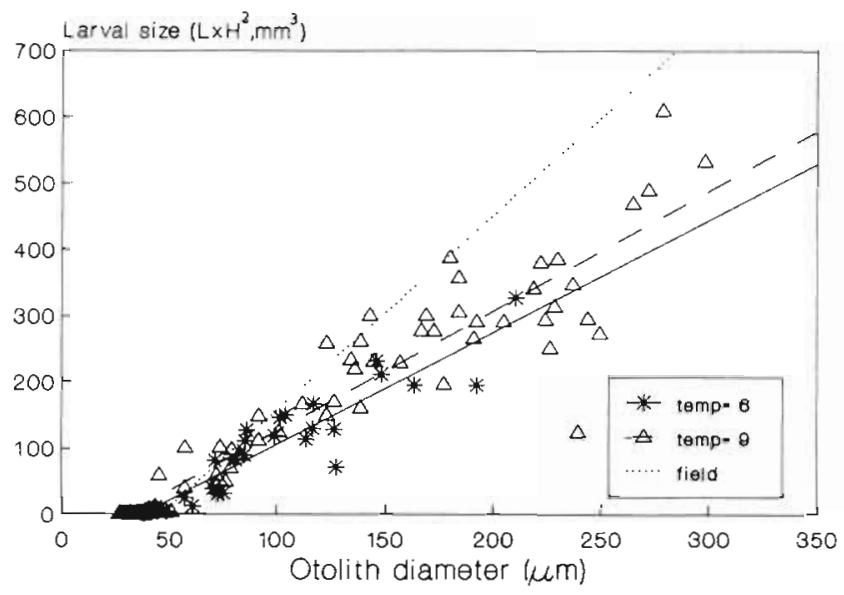

Fig. 5. Pleuronectes platessa. Regression of larval size $\left(\mathrm{L} \times \mathrm{H}^{2}\right)$ on otolith diameter (OD) for larvae reared at 6 and $9{ }^{\circ} \mathrm{C} .6^{\circ} \mathrm{C}$ $\mathrm{L} \times \mathrm{H}^{2}=-63+1.689$ OD, $\mathrm{r}=0.94, \mathrm{~N}=34 ; 9^{\circ} \mathrm{C}: \mathrm{L} \times \mathrm{H}^{2}=-55$ $+1.808 \mathrm{OD}, \mathrm{r}=0.94, \mathrm{~N}=73$. Regression line from field data is plotted for comparison

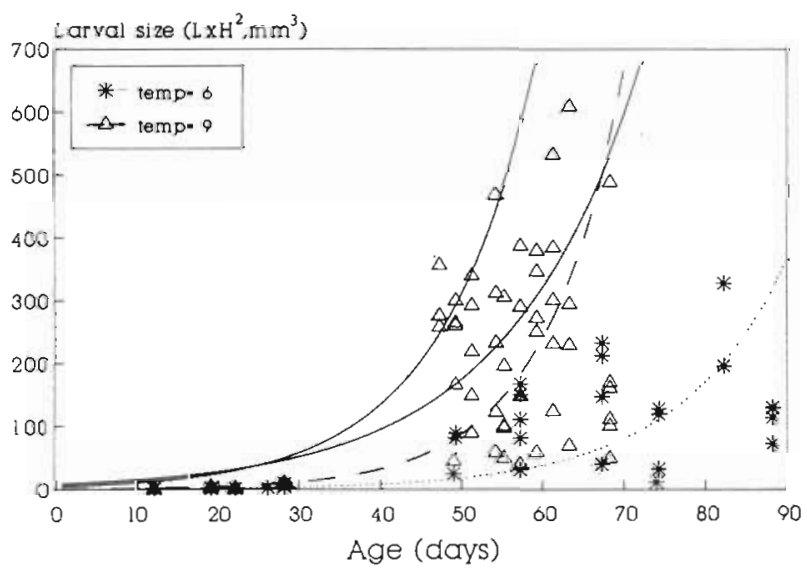

Fig. 6. Pleuronectes platessa. Relationship between age (days) and larval size $\left(\mathrm{L} \times \mathrm{H}^{2}\right)$ for larvae reared at 6 and $9^{\circ} \mathrm{C}$. Exponential growth curves fitted: $6^{\circ} \mathrm{C}: \mathrm{L} \times \mathrm{H}^{2}=0.42 \exp (0.0756$ d) $9^{\circ} \mathrm{C}: \mathrm{L} \times H^{2}=0.58 \exp (0.1007$ d)

vae reared at $6^{\circ} \mathrm{C}$ seemed to be larger relative to body size, the differences between fitted linear regressions were not significant.

Size is plotted against age for $6^{\circ} \mathrm{C}$ and $9^{\circ} \mathrm{C}$ in Fig. 6 Somatic growth can be described by:

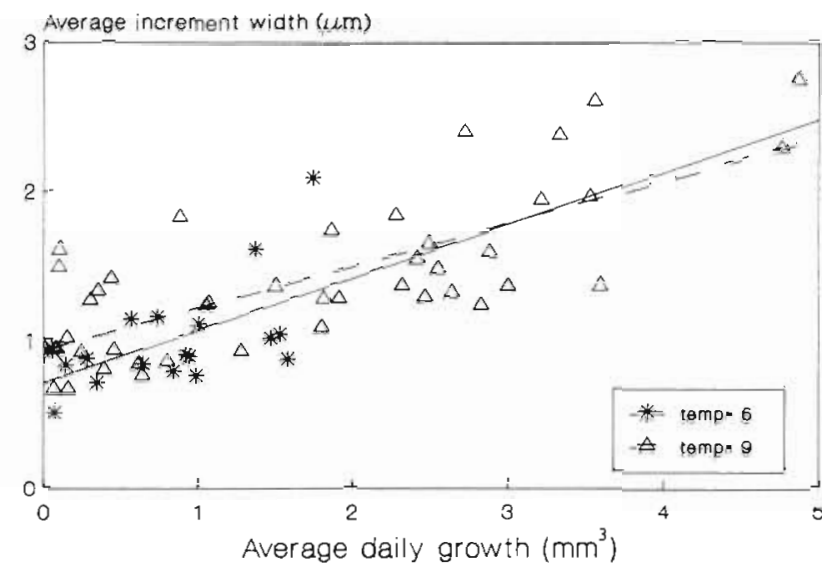

Fig. 7. Pleuronectes platessa. Regressions of average daily increment width (AIW) on daily growth in $\mathrm{L} \times \mathrm{H}(\mathrm{DG})$ for larvae reared at 6 and $9^{\circ} \mathrm{C} .6^{\circ} \mathrm{C}: \mathrm{AIW}=0.918+0.283 \quad \mathrm{DG}, \mathrm{r}=0.71$, $\mathrm{N}=44 ; 9^{\circ} \mathrm{C}: \mathrm{AIW}=0.682+0.375 \quad \mathrm{DG}, \mathrm{r}=0.61, \mathrm{~N}=20$

$\mathrm{L} \times \mathrm{H}^{2}=0.42 \cdot \exp (0.0756 \cdot$ age $) \quad\left(6^{\circ} \mathrm{C}\right)$

$\mathrm{L} \times \mathrm{H}^{2}=0.58 \cdot \exp (0.1007$ age $)\left(9^{\circ} \mathrm{C}\right)$

Differences between slopes were significant ( $p<$ $0.001)$. Mortality was high during the first weeks of the experiments, and growth slow. It is suspected that food supply may not have been fully adequate during this period, which may have caused the large variation in growth rates.

Average daily otolith growth is plotted against average daily somatic growth for both temperatures (Fig. 7). The correlation coefficient (for both temperatures combined) is $0.759(\mathrm{~N}=62, \mathrm{p}<0.001)$, indicating a highly significant, albeit rather poor, relationship.

Average size $\left(\mathrm{L} \times \mathrm{H}^{2}\right)$ per stage is given in Table 2 . Differences between temperatures are significant $(\mathrm{p}=$ 0.031 ), with larvae reared at $9^{\circ} \mathrm{C}$ having attained a larger size at the same stage than larvae reared at $6^{\circ} \mathrm{C}$.

\section{Field data}

Larvae caught at sea were divided in 2 groups, with larvae caught on 8-9 March in Group 1 and larvae

Table 2. Means, standard deviations and numbers per stage of: length, $\mathrm{L} \times \mathrm{H}^{2}$ and dry weight for larvae reared at $6^{\circ} \mathrm{C}$ and $9{ }^{\circ} \mathrm{C}$. Weights calculated according to Equation 2

\begin{tabular}{|c|c|c|c|c|c|c|c|c|c|c|c|c|c|c|}
\hline \multirow{3}{*}{ Stage } & \multicolumn{7}{|c|}{$6^{\circ} \mathrm{C}$} & \multicolumn{7}{|c|}{$9^{\circ} \mathrm{C}$} \\
\hline & \multicolumn{2}{|c|}{ Length ( $\mathrm{mm}$ ) } & \multicolumn{2}{|c|}{$\mathrm{L} \times \mathrm{H}^{2}\left(\mathrm{~mm}^{3}\right)$} & \multicolumn{2}{|c|}{ Weight $\left(10^{-5} \mathrm{~g}\right)$} & \multirow[b]{2}{*}{$N$} & \multicolumn{2}{|c|}{ Length $(\mathrm{mm})$} & \multicolumn{2}{|c|}{$\mathrm{L} \times \mathrm{H}^{2}\left(\mathrm{~mm}^{3}\right)$} & \multicolumn{2}{|c|}{ Weight $\left(10^{-5} \mathrm{~g}\right)$} & \multirow[b]{2}{*}{$\mathrm{N}$} \\
\hline & Mean & SD & Mean & $\mathrm{SD}$ & Mean & $\mathrm{SD}$ & & Mean & $\mathrm{SD}$ & Mean & $\mathrm{SD}$ & Mean & $\mathrm{SD}$ & \\
\hline 1 & 7.78 & 0.25 & 0.8 & 0.22 & 20.05 & 0.16 & 19 & 7.48 & 0.50 & 1.0 & 0.3 & 20.22 & 0.45 & 14 \\
\hline 2 & 8.37 & 0.40 & 30.0 & 2.89 & 23.03 & 4.04 & 12 & 8.22 & 0.31 & 2.4 & 1.4 & 22.17 & 2.05 & 8 \\
\hline 3 & 8.54 & 0.73 & 26.9 & 8.82 & 56.34 & 12.31 & 5 & 8.67 & 0.63 & 36.4 & 21.6 & 69.58 & 30.12 & 7 \\
\hline 4 & 10.74 & 0.64 & 129.7 & 45.91 & 199.75 & 64.15 & 14 & 10.46 & 1.13 & 157.3 & 79.4 & 238.23 & 110.78 & 19 \\
\hline 5 & 10.86 & 0.48 & 210.3 & 72.00 & 312.21 & 100.45 & 4 & 12.10 & 0.86 & 312.5 & 108.5 & 466.98 & 151.26 & 26 \\
\hline
\end{tabular}




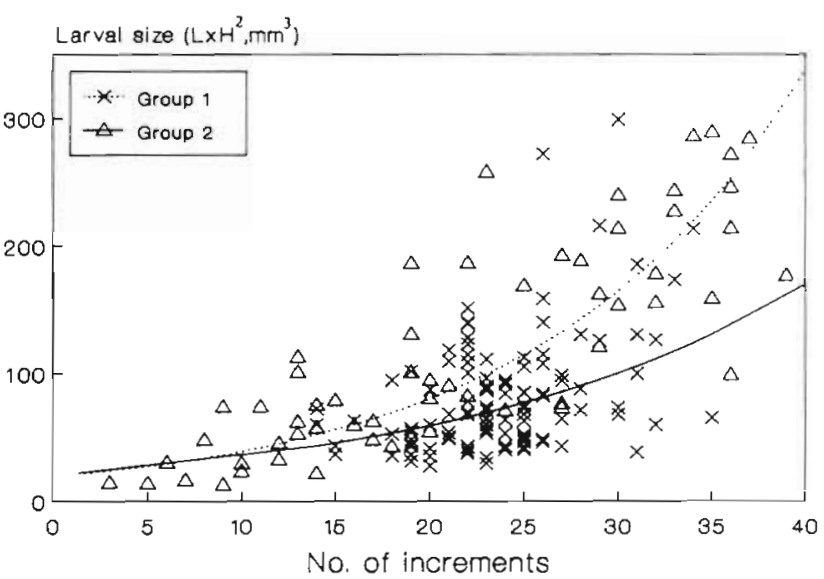

Fig. 8. Pleuronectes platessa. Relationship between number of increments (NI) and larval size $\left(\mathrm{L} \times \mathrm{H}^{2}\right)$ for larvae caught at 8-9 March (Group 1) and 22 March (Group 2). Exponential growth curves fitted. Group 1. L $\times \mathrm{H}^{2}=20.98 \exp (0.052 \mathrm{NI})$; Group 2: $\mathrm{L} \times \mathrm{H}^{2}=20.06 \exp (0.071 \cdot \mathrm{NI})$

caught on 22 March in Group 2. Size $\left(\mathrm{L} \times \mathrm{H}^{2}\right)$ was plotted against increment count for both groups (Fig. 8), and exponential growth curves were fitted:

$\mathrm{L} \times \mathrm{H}^{2}=20.98 \exp (0.0522 \cdot$ no. of increments $)$ (Group 1)

$\mathrm{L} \times \mathrm{H}^{2}=20.06 \cdot \exp (0.0713$ no. of increments)

(Group 2)

Converted into dry weights (according to equation 4) this yields:

$\mathrm{DW}=41.5 \exp (0.045$ no. of increments $)$

(Group 1)

$D W=40.5 \exp (0.063$ no. of increments $)$

(Group 2) (10)

Differences between slopes were almost significant ( $p$ $=0.065$ ).

Increments formed during yolk-sac stage are probably too small or too vague for light microscopical resolution so the number of increments is used as an indication of age rather than age itself, and probably represents the number of days since first feeding

Average size $\left(\mathrm{L} \times \mathrm{H}^{2}\right)$ per stage is given in Table 3 for each group. Larvae from Group 2 were larger than larvae of Group 1 at the same stage from Stage $3 b$ upwards. Differences between groups were significant $(p<0.001)$.

\section{Otolith growth}

Fish size is plotted against otolith diameter for each group (Fig. 9). The difference between the lines is highly significant $(\mathrm{p}<0.01)$, larvae of Group 2 having relatively smaller otoliths. Average otolith increment

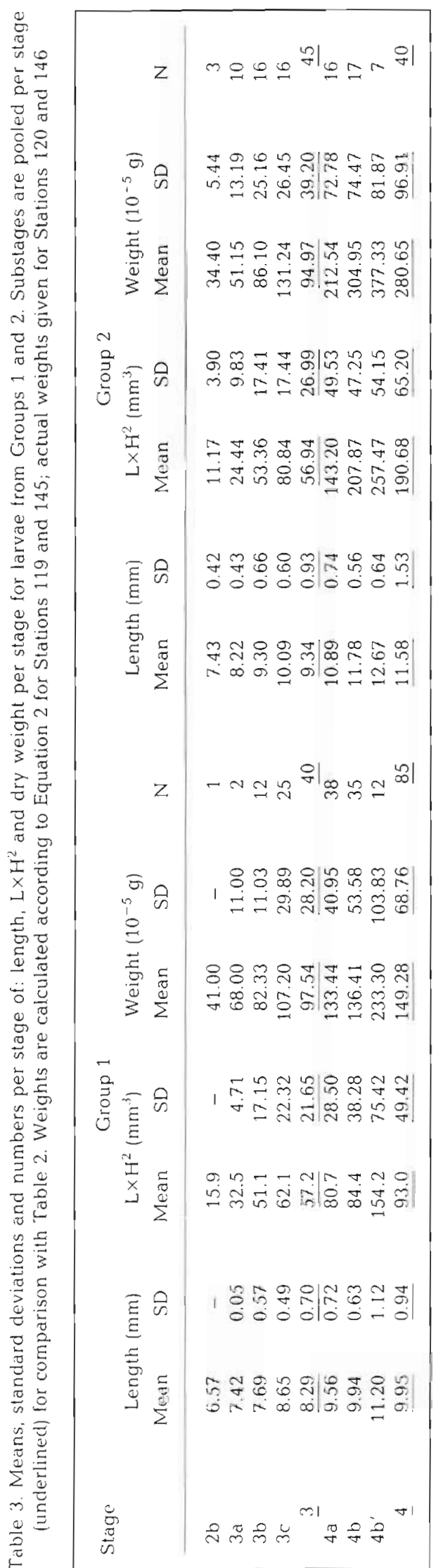




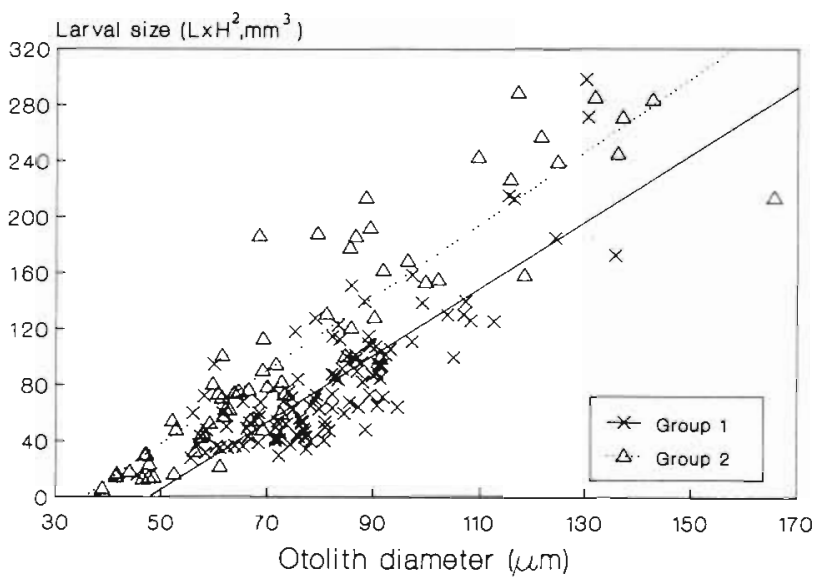

Fig. 9. Pleuronectes platessa. Regression of larval size $\left(\mathrm{L} \times \mathrm{H}^{2}\right)$ on otolith diameter (OD) for larvae caught at 8-9 March (Group 1) and 22 March (Group 2). Group 1: $\mathrm{L} \times \mathrm{H}^{2}=-114.6$ $+2.399 \mathrm{OD}, \mathrm{r}=0.82, \mathrm{~N}=112$; Group 2: $\mathrm{L} \times \mathrm{H}^{2}=-93.5+$ $2.634 \mathrm{OD}, \mathrm{r}=0.91, \mathrm{~N}=64$

Table 4. Means and standard deviations of widths of increments 1 to 10,11 to 20 and 21 to 30 for larvae from Groups 1 and 2

\begin{tabular}{|lrrrrrr|}
\hline Incr & \multicolumn{3}{c}{ Group 1 } & \multicolumn{3}{c}{ Group 2 } \\
no. & Mean & SD & N & Mean & SD & $N$ \\
\hline $1-10$ & 0.784 & 0.124 & 112 & 0.791 & 0.179 & 50 \\
$11-20$ & 1.123 & 0.224 & 95 & 0.988 & 0.284 & 31 \\
$21-30$ & 1.466 & 0.401 & 11 & 1.534 & 0.288 & 13 \\
\hline
\end{tabular}

widths for increment 1 to 10,11 to 20 , and 20 to 30 are given in Table 4. No differences were found between widths of increment 1 to 10 , and 21 to 30 , but width of increment 11 to 20 is slightly larger in Group 1 (t-test, $0.05>p>0.01$ )

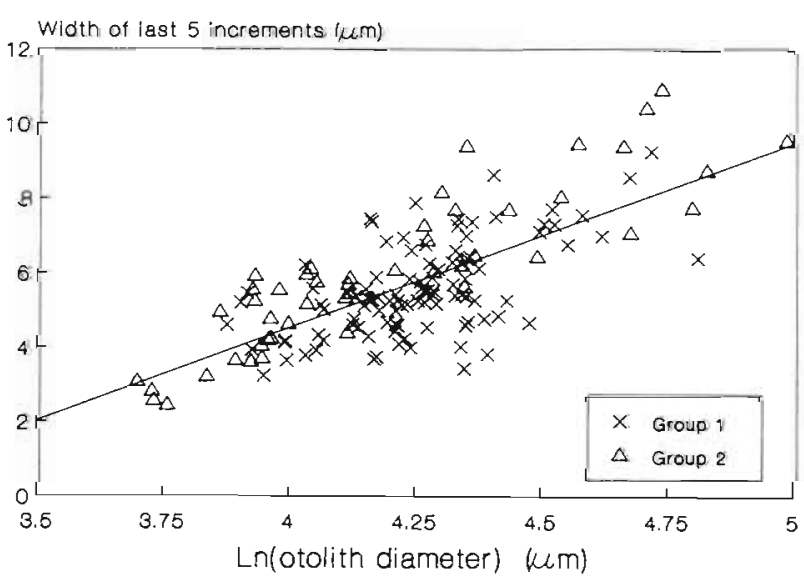

Fig. 10. Pleuronectes platessa. Relation between of the sum of the last 5 increments (S5) on the natural logarithm of the otolith diameter at the start of formation of the last 5 increments, for larvae from Groups 1 and 2. Linear regression line plotted for pooled data: $55=-15.439+4.99$ Ln (OD), $r=0.73, N=151$
Table 5. Means and standard deviations of the residuals from the regression of the width of the outer 5 increments on Ln (otolith diameter) for larvae from Groups 1 and 2

\begin{tabular}{|cccc|}
\hline Group & Mean residual & SD & $N$ \\
\hline 1 & -0.264 & 1.206 & 103 \\
2 & 0.525 & 0.977 & 49 \\
\hline
\end{tabular}

The relation between the sum of the width of the last 5 complete increments and the natural logarithm of the otolith diameter minus this width is plotted in Fig. 10. A linear relationship was observed, and the (pooled) residuals showed no trends. When calculated for both groups separately, residuals were significantly higher for Group 2 than Group 1 (Table 5, t-test, p<0.001) indicating faster growth over the last $5 \mathrm{~d}$ for Group 2.

\section{RNA/DNA ratios}

Means and standard deviations of RNA/DNA ratios of starving and sea-caught larvae are plotted in Fig. 11.

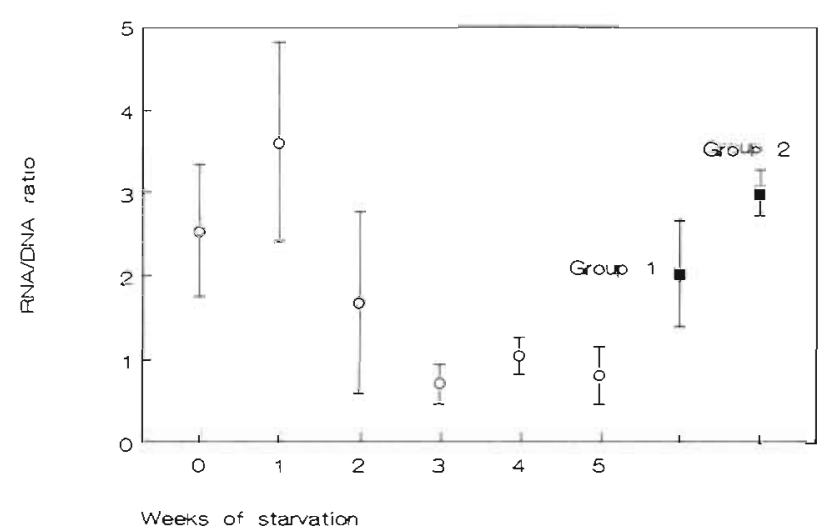

Fig. 11. Pleuronectes platessa. Means and standard deviations of RNA/DNA ratios of starving larvae (laboratory) and of larvae from 8-9 March 9 (Group 1) 22 March (Group 2)

Length, $\mathrm{L} \times \mathrm{H}^{2}$, calculated dry weight, stage and RNA/ DNA ratios of individual sea-caught larvae are given in Table 6. There was no relation between RNA/DNA and size or developmental stage. RNA/DNA ratios are significantly higher in Group 2 than in Group 1 (MannWhitney U-test, $\mathrm{p}<0.001$ ).

In the starvation experiment, the RNA/DNA ratios declined until Week 3 (apart from the erratic difference between Week 0 and 1, which was not significant), after which RNA/DNA ratios are constant at ca 1. Mortality during these experiments was practically zero, apart from some mortality within 1 to $2 \mathrm{~d}$ of capture, which must be ascribed to the capture and handling of the larvae. 
Table 6. Length, $\mathrm{L} \times \mathrm{H}^{2}$, calculated dry weight, stage, RNA/DNA ratio and daily protein growth rate (Pr.gr.r.) of larvae from Group 1 and 2. Means, standard deviations and number of larvae given in lower part of table

\begin{tabular}{|c|c|c|c|c|c|c|c|c|c|c|c|}
\hline \multicolumn{6}{|c|}{ Group 1} & \multicolumn{6}{|c|}{ Group 2} \\
\hline $\begin{array}{l}\text { Length } \\
(\mathrm{mm})\end{array}$ & $\begin{array}{l}\mathrm{L} \times \mathrm{H}^{2} \\
\left(\mathrm{~mm}^{3}\right)\end{array}$ & $\begin{array}{l}\text { Weight } \\
\left(10^{-5} \mathrm{~g}\right)\end{array}$ & Stage & RNA/DNA & $\begin{array}{l}\text { Pr.gr.r } \\
\left(\% \mathrm{~d}^{-1}\right)\end{array}$ & $\begin{array}{l}\text { Length } \\
(\mathrm{mm})\end{array}$ & $\begin{array}{l}\mathrm{L} \times \mathrm{H}^{2} \\
\left(\mathrm{~mm}^{3}\right)\end{array}$ & $\begin{array}{l}\text { Weight } \\
\left(10^{-5} \mathrm{~g}\right)\end{array}$ & Stage & RNA/DNA & $\begin{array}{l}\text { Pr.gr.r } \\
\left(\% d^{-1}\right)\end{array}$ \\
\hline 9.4 & 87.44 & 140.79 & $4 b$ & 2.489 & -0.68 & 11.8 & 218.18 & 323.17 & $4 b$ & 3.363 & 4.02 \\
\hline 9.4 & 45.50 & 82.28 & $4 \mathrm{a}$ & 1.408 & -5.82 & 12.2 & 210.11 & 311.92 & $4 b^{\prime}$ & 2.937 & 2.00 \\
\hline 11.4 & 147.74 & 224.91 & $4 b$ & 2.382 & -1.19 & 11.9 & 42.96 & 78.74 & $3 c$ & 2.628 & 0.54 \\
\hline 10.2 & 26.11 & 55.24 & $3 a$ & 1.196 & -6.83 & 11.5 & 125.24 & 193.51 & $4 a$ & 3.036 & 2.47 \\
\hline 9.3 & 72.91 & 120.52 & $4 a$ & 3.032 & 1.90 & 13.9 & 281.48 & 411.47 & $4 \mathrm{~b}$ & 2.752 & 1.12 \\
\hline 11.85 & 125.17 & 193.42 & $4 b$ & 0.790 & -8.75 & 11 & 116.19 & 180.89 & $4 \mathrm{a}$ & 3.169 & 3.10 \\
\hline 11.4 & 116.74 & 181.66 & $4 b$ & 0.720 & -9.09 & 9.4 & 58.75 & 100.77 & $3 c$ & 3.522 & 4.78 \\
\hline 10 & 115.60 & 180.07 & $4 \mathrm{a}$ & 1.892 & -3.52 & 12.3 & 125.95 & 194.51 & $4 \mathrm{~b}$ & 2.966 & 2.14 \\
\hline 11.9 & 209.92 & 311.64 & $4 b$ & 2.437 & -0.93 & 11.5 & 212.64 & 315.44 & $4 \mathrm{~b}$ & 2.771 & 1.21 \\
\hline 11.7 & 187.20 & 279.95 & $4 b$ & 2.287 & -1.65 & 9.65 & 31.27 & 62.43 & $3 b$ & 3.074 & 2.65 \\
\hline 11.2 & 183.71 & 275.08 & $4 a$ & 2.552 & -0.39 & 11.5 & 202.86 & 301.80 & $4 b$ & 2.791 & 1.31 \\
\hline 10.2 & 53.96 & 94.08 & $3 c$ & 1.686 & -4.50 & & & & & & \\
\hline 10.6 & 95.40 & 151.89 & $4 b$ & 1.567 & -5.06 & & & & & & \\
\hline 13.13 & 341.38 & 495.04 & $4 b^{\prime}$ & 2.532 & -0.48 & & & & & & \\
\hline 11.85 & 153.58 & 233.05 & $4 b$ & 2.530 & -0.49 & & & & & & \\
\hline 11.75 & 62.16 & 105.52 & $4 b$ & 2.816 & 0.87 & & & & & & \\
\hline 10.9 & 91.67 & 146.69 & $4 b$ & 1.809 & -3.92 & & & & & & \\
\hline 10.75 & 67.19 & 112.54 & $4 \mathrm{~b}$ & 2.423 & -1.00 & & & & & & \\
\hline 9.55 & 57.32 & 98.78 & $4 a$ & 0.897 & -8.25 & & & & & & \\
\hline 11.7 & 160.17 & 242.25 & $4 b^{\prime}$ & 2.023 & -2.90 & & & & & & \\
\hline 10.2 & 38.79 & 72.92 & $4 a$ & 1.502 & -5.37 & & & & & & \\
\hline 12 & 115.32 & 179.68 & $4 b$ & 2.553 & -0.38 & & & & & & \\
\hline 10.3 & 92.70 & 148.13 & $4 \overline{\mathrm{a}}$ & 2.232 & -1.91 & & & & & & \\
\hline 10.1 & 73.63 & 121.52 & $4 \mathrm{a}$ & 1.895 & -3.50 & & & & & & \\
\hline 10.25 & 59.04 & 101.17 & $4 a$ & 2.092 & -2.57 & & & & & & \\
\hline 9.2 & 28.18 & 58.11 & $3 \mathrm{c}$ & 3.043 & 1.95 & & & & & & \\
\hline 10.78 & 108.02 & 169.50 & & 2.030 & -2.86 & 11.51 & 147.78 & 224.97 & & 3.001 & 2.30 \\
\hline 1.02 & 68.12 & 95.02 & & 0.644 & $\begin{array}{r}3.06 \\
26\end{array}$ & 1.18 & 78.87 & 110.03 & & 0.259 & $\begin{array}{r}1.23 \\
11\end{array}$ \\
\hline
\end{tabular}

\section{DISCUSSION AND CONCLUSIONS}

\section{Size-weight relationships}

It is shown that the otolith diameter provides a reasonable estimate for the dry weight of the larvae (Fig. 4). In most research on larval fish only standard or fork length is correlated with otolith size, which leaves the relation between larval weight and otolith size to be calculated. During this study most of the otoliths proved to be resistant to $70^{\circ} \mathrm{C}$ for $40 \mathrm{~h}$, thus providing a direct relationship.

\section{Larval growth}

Growth rates of the laboratory-reared larvae were higher at 9 than at $6^{\circ} \mathrm{C}$, although at both temperatures there was a large amount of variation in size-at-age. This variation may be an indication that growth has not been optimal, under the given temperature. As initial mortality was high, and growth slow, it is possible that only fast growing individuals survived until metamor- phosis, thereby influencing the form of the growth curve and yielding overestimates of growth rates.

Growth rates of the field-caught larvae cannot be directly compared to the laboratory-reared larvae, because the number of increments is not equal to the actual age of the larvae. It was estimated from laboratory results that initial growth of the otoliths was ca 1.2 $\mu \mathrm{m} \mathrm{d}^{-1}$, and the actual age of the larve was estimated, assuming that the otoliths grew this much until the first light microscopical visible increment had formed. Calculated this way, the larvae were on the average ca 17 d old before the first increment was formed, which, according to Ryland (1966) would be at the beginning of Stage 2. In this study only 4 larvae of Stage $2 b$ were found, with increment numbers between 0 and 3 , indicating that increments are indeed not formed before Stage 2

Growth rates were recalculated as:

Group $1 \mathrm{~L} \times \mathrm{H}^{2}=8.39 \exp (0.061$ estimated age) (11) Group 2: $\mathrm{L} \times \mathrm{H}^{2}=4.76 \exp (0.084 \cdot$ estimated age) (12) Comparison with Equations 5 and 6 (Fig. 6) shows that 
initial growth temperatures were about the same $\left(6^{\circ} \mathrm{C}\right)$ or higher $\left(9^{\circ} \mathrm{C}\right)$.

Average daily otolith growth is correlated with average daily somatic growth, with no significant effect of temperature, and the average increment width can be used as an indication of somatic growth. However, this relationship is not very strong $\left(\mathrm{r}^{2}=0.576\right)$ and care must be taken when analyzing small samples

Initial slow growth of the laboratory-reared larvae is shown as well by a comparison of size at stage with the field-caught larvae (Tables 2 and 3). Moreover, larvae reared at $9^{\circ} \mathrm{C}$ are larger than at $6^{\circ} \mathrm{C}$ at the same stage. In the field samples, size at Stages 3 and 4 is larger than in laboratory-reared larvae at both temperatures. Size at stage may thus be an indication of growth rate that is quick and easy to assess. A comparison of size at stage between the field samples shows that larvae in Group 2 were larger than in Group 1 from Stage $3 b$ to $4 \mathrm{~b}$, again indicating faster growth for the late larvae.

The difference in regressions of larval size on otolith size (Figs. 5 and 9) agrees with the literature data (Marshall \& Parker 1982, Post \& Prankevicius 1987, Mosegaard et al. 1988, Secor \& Dean 1989), with otoliths of the faster growing larvae being relatively smaller, although a larger difference would be expected between the larvae reared at 6 and $9^{\circ} \mathrm{C}$. Otoliths of the laboratory-reared larvae are relatively large compared to the otoliths of the field-caught larvae, confirming poor growth conditions in the laboratory (Fig. 5). If a common regression is used in back-calculating somatic growth, this will yield an overestimate in case of slow growth, and an underestimate in case of fast growth, thus levelling actual growth differences.

\section{Recent growth}

In the field data analysis of widths of the first 30 increments (per 10 increments), there was a small difference between increments 11 to 20 , these being wider in the first group. But when only the last 5 increments are analyzed, it appears that growth has been faster in Group 2 during the last $5 \mathrm{~d}$. Are the differences in the otolith diameter-body size relation (Fig. 9) formed throughout the whole life of the larvae, or by faster growth only during the last few days? Suppose that both groups of larvae initially were growing with a the same growth rate, and consider 2 larvae with a size of $60 \mathrm{~mm}^{3}$. If one larva stops growing altogether, and the other larva grows with a growth rate of 0.06 , then in $5 \mathrm{~d}$ the growing larva will have reached a size of $81 \mathrm{~mm}^{3}$ and in $10 \mathrm{~d}$ a size of $109 \mathrm{~mm}^{3}$. The actual magnitude of differences in size between Group 1 and 2 (Fig. 8) falls well within this range, so indeed the differences could be explained by recent faster growth in Group 2. The differences in growth between Group 1 and Group 2 might be related to the temperature, which at the day of capture was $6.1^{\circ} \mathrm{C}$ for Group 1, and $6.7^{\circ} \mathrm{C}$ for Group 2.

The $Q_{10}$ of fish larvae can be estimated at ca 2.5. which means a ca $10 \%$ increase in growth rate per degree (if no food limitation occurs). The difference observed in the growth rates of the laboratory-reared larvae can be explained this way, however, the difference in growth rate between Groups 1 and 2 in ca $35 \%$, and greater than would be expected with temperature as the only factor responsible.

\section{RNA/DNA ratios}

Additional support for recent differences in growth rate may be derived from the RNA/DNA ratios. RNA/ DNA ratios have been used in several field and laboratory studies to assess recent growth, and have been shown to decrease with decreasing food ratios or after periods of starvation (Buckley 1979, 1982, 1984, Buckley et al. 1984, Wright \& Martin 1985, Buckley \& Lough 1987, Clemmesen 1987, Robinson \& Ware 1988).

According to Buckley (1984) the RNA/DNA ratio is related to water temperature and daily protein growth rate (DPGR) as

DPGR $=0.93$ Temperature + 4.75 RNA/DNA -18.18

a relationship that held true for 8 different species of fish larvae. When protein growth rate is set to zero, this equation can be rewritten as:

RNA/DNA $=(18.18-0.93 \cdot$ Temperature $) / 4.75$

This RNA/DNA ratio, at which no protein growth rate takes place has been called the 'critical ratio' (Robinson \& Ware 1988). For temperatures of $6.1^{\circ} \mathrm{C}$ (Group 1) and $6.7^{\circ} \mathrm{C}$ (Group 2) critical ratios were 2.63 and 2.51 , respectively. From Group 2, none of 11 larvae below the critical ratio, but from Group 1, 23 larvae out of 26 $(88 \%)$ had a RNA/DNA ratio below this ratio. On the average, a negative daily protein growth rate $(-2.9 \%)$ was calculated for Group 1 and a positive daily protein growth rate (2.3\%) for Group 2. Ehrlich (1974) showed that, in plaice larvae, protein is being used from the start of starvation, and negative protein growth rates will thus be found even after short periods or starvation.

The results from the starvation experiment show that a RNA/DNA ratio of ca 2 is reached after a period of 1 to 2 wk of starvation, but this period may be different for the younger larval stages.

Summarizing the evidence, it seems plausible that the observed growth differences are of recent origin (5 
to $20 \mathrm{~d}$ ) and that they are caused by a combination of food abundance and temperature, in which food abundance must have played a significant role. The possible effect of short periods of starvation on mortality are almost impossible to assess in the field. Direct mortality because of starvation will probably not be very important, as the Point-of-No-Return (at 9 to $10^{\circ} \mathrm{C}$ ) for starving plaice larvae (Stage 3 ) is ca 10 to $18 \mathrm{~d}$, and will probably be even more for older larvae and lower temperatures (Blaxter \& Ehrlich 1974). Indirect mortality by enhanced vulnerability to predation may be important, depending on larval size (Bailey 1984, Bailey \& Batty 1984, Bailey \& Yen 1984), but sizeselective mortality has been demonstrated in predatorfree enclosures as well (Rosenberg \& Haugen 1982); a quantitative assessment of its importance cannot be given at this stage.

With a negative growth, as in the larvae of Group 1 , increment widths cannot directly be used as a reliable measure of previous somatic growth, because of the conservative reaction of the otoliths on growth, and short periods of food limitation or starvation will probably not be detected. However, if this argument is reversed, it follows that when differences in otolith growth actually are found, they must have been caused by even larger differences in somatic growth. The use of otolith growth data as an indication of somatic growth may thus be limited to comparative analyses, but it is not invalidated. Furthermore is it possible that the size of the otolith follows from these results that great care must be taken when the relationship between larval size and otolith size is used as a shrinkage estimator, especially when larvae are not from the same population, as has been done by Leak (1986) and Leak \& Houde (1987).

RNA/DNA ratios seem to provide a sensitive method to detect short-term growth differences and periods of starvation, but, thus far, measurements of RNA/DNA ratios from wild fish larvae are scarce. This is, to my knowledge, the first study in which RNA/DNA ratios, size-at-age data, and otolith increment widths are combined, and the results are consistent.

The consequences of differences in growth for mortality, immigration, and ultimately recruitment, may be important. The possibility of detecting and back-dating such differences may be another step towards a better understanding of these processes.

Acknowledgements. I am indebted to M.A. G. Verdijk for her work with the larvae in the laboratory, and to J. IJ. Witte for all his assistance. C. Clemmesen and $M$. Veldhuis are thanked for their advice on RNA/DNA analysis. During collection of the samples, the assistance of the crew of the R. V. Aurelia has been indispensible. The manuscript greatly benefitted from Dr J. J. Zijlstra's critical comments and from the criticism of an anonymous referee.

\section{LITERATURE CITED}

Bailey. K. M. (1982). The early life history of the Pacific hake Merluccius productus. Fish. Bull. U.S. 80: 589-598

Bailey, K. M. (1984). Comparison of laboratory rates of predation on five species of marine fish larvae by three planktonic invertebrates: Effects of larval size on vulnerability. Mar Biol. 79: 303-309

Bailey, K. M. Batty. R. S. (1984). Laboratory study of predation by Aurelia aurita on larvae of cod, flounder, plaice and herring: development and vulnerability to capture. Mar. Biol. 83: 287-291

Bailey, K. M. , Stehr, C. L. (1988). The effects of feeding periodicity and ration on the rate of increment formation in otoliths of larval walleye pollock Theragra chalcogramma (Pallas). J. exp. mar Biol. Ecol., 122: 147-161

Bailey, K. M., Yen, J. (1984). Predation by a carnivorous copepod, Euchaeta elogata Esterly, on the eggs and larvae of the Pacific hake. J. Plankton Res. 5: 71-82

Bannister, R. C. A., Harding, D., Lockwood, S. J. (1974). Larval mortality and subsequent yearclass-strength in the plaice (Pleuronectes platessa). In: Blaxter. J. H. S. (ed.). The early life history of fish. Springer Verlag, Berlin, p. 21-37

Barkman, R. C., Bengtson, D. A. (1987). The record of daily growth in otoliths of Atlantic silversides, Menidia menidia, from field and laboratory. J. Fish Biol. 31: 683-695

Blaxter, J. H. S., Ehrlich, K. F. (1974). Changes in the behaviour during starvation of herring and plaice larvae. In: Blaxter, J. H. S. (ed.). The early life history of fish. Springer Verlag, Berlin, p. 575-588

Buckley, L. J. (1979). Relationships between RNA-DNA ratio, prey density, and growth rate in Atlantic cod (Gadus morhual larvae. J. Fish. Res. Bd Can. 36: 1497-1502

Buckley, L. J. (1982). Effects of temperature on growth and biochemical composition of larval winter flounder Pseudopleuronectes americanus. Mar. Ecol. Prog. Ser. 8: 181-186

Buckley, L. J. (1984). RNA-DNA ratio: an index of larval fish growth in the sea. Mar Biol 80: 291-298

Buckley, L. J., Lough, R. G. (1987). Recent growth, biochemical composition, and prey field of larval haddock (Melanogrammus aeglefinus) and Atlantic cod (Gadus morhua) on Georges Bank. Can. J. Fish. aquat. Sci. 44: 14-25

Buckley, L. J., Turner, S. I., Halvik, T. A., Smigielski, A. S., Dres, S. M., Laurence, G. C. (1984). Effects of temperature and food availability on growth, survival, and RNA-DNA ratio of larval sand lance (Ammodytes americanus). Mar. Ecol. Prog. Ser. 15: 91-97

Campana, S. E., Neilson, J. D. (1985). Microstructure of fish otoliths. Can. J. Zool. 42: 1014-1032

Clemmesen, C. M. (1987). Laboratory studies on RNA/DNA ratios of starved and fed herring (Clupea harengus) and turbot (Scophthalmus maximus) larvae. J. Cons. int. Explor Mer. 43: 122-128

Clemmesen, C. M. (1988). A RNA and DNA fluorescence technique to evaluate the nutritional condition of individual marine fish larvae. Meeresforsch. Rep. mar. Res. 32: $134-143$

Ehrlich, K. F. (1974). Chemical changes during growth and starvation of larval plaice. Pleuronectes platessa. Mar. Biol $24: 39-48$

Geffen, A. J. (1982). Otolith ring deposition in relation to growth rate in herring (Clupea harengus) and turbot (Scopthalmicus maximus) larvae. Mar. Biol. 71: 317-326

Govoni, J. J. Chester, A. J., Hoss, D. E, Ortner, P. B. (1985). An observation of episodic feeding and growth of larval. Leiostomus xanthurus in the northern Gulf of Mexico. J. Plankton Res. 7. 137-146 
Harding, D., Nichols, J. H., Tungate, D. S. (1978). The spawning of the plaice (Pleuronectes platessa L.) in the southern North Sea and English Channel. Rapp. R.-v. Réun. Cons. int. Explor. Mer. 172: 102-113

Hovenkamp, F. (1989). Within-season variation in growth of larval plaice (Pleuronectes platessa L.). Rapp. P.-v. Réun. Cons. int. Explor Mer (in press)

Jones, C. (1986). Determining age of larval fish with the otolith increment technique. Fish. Bull. U.S. 84: 91-103

Karakiri, M., Westernhagen, H. von (1989). Daily growth patterns in otoliths of larval and postlarval plaice (Pleuronectes platessa L.): influence of temperature, salinity and light conditions. Rapp. P.-v. Réun. Cons. int. Explor. Mer (in press)

Lea, E. (1910). On the methods used in herring investigation. Cons. Perm. Int. Explor. Mer., Publ. Circonstance 53

Leak, J. C. (1986). The relationship of standard length and otolith diameter in larval Bay anchovy, Anchoa mitchilli (Val.). A shrinkage estimator. J. exp. mar. Biol. Ecol. 95: $167-172$

Leak, J. C., Houde, E. D. \{1987\}. Cohort growth and survival of Bay anchovy Anchoa mitchilli larvae in Biscayne Bay, Florida. Mar. Ecol. Prog. Ser 37: 109-122

Lee, R. M. (1912). An investigation into the methods of growth determination in fishes. Cons. Perm. Int. Explor Mer., Publ. Circonstance 63

Lough, R. G., Pennington, M., Bolz, G. R, Rosenberg, A. (1982). Age and growth of larval Atlantic herring, Clupea harengus L., in the Gulf of Maine-Georges Bank region based on otolith growth increments. Fish. Bull. U.S. 80: $187-200$

Marshall, S. L., Parker, S. S. (1982). Pattern identification in the microstructure of sockeye salmon (Oncorhynchus nerka) otoliths. Can. J. Fish. aquat. Sci. 39: 542-547

McGurk, M. D. (1984). Effects of delayed feeding and temperature on the age of irreversible starvation and on the growth rates and mortality of Pacific herring larvae. Mar Biol. 84: 13-26

Method., R. D. (1981). Spatial covariation of daily growth rates of larval northern anchovy, Engraulis mordax and northern lampfish. Stenobrachius leucopsarus. Rapp. P.-v. Réun, Cons. int. Explor. Mer 178: 424-431

Method, R. D., Kramer, D. A. (1979). Growth of northern anchovy, Engraulis mordax, larvae in the sea. Fish. Bull. U.S. 77 : 413-423

Mosegaard, H., Svedäng, H, Taberman, K. (1988). Uncoupling of somatic and otolith growth rates in Arctic Char (Salvelinus alpinus) as an effect of differences in temperature response. Can. J. Fish. aquat. Sci. 45: 1514-1524

Mosegaard, H., Titus, R. (1987). Daily growth rates of otoliths in yolk sac fry of two salmonid species at five different

This article was submitted to the editor temperatures. Proc. V cong. eur. Ichthyol, Stockholm 1985, p. 221-227

Neilson, J. D., Geen, G. H. (1982). Otoliths of chinook salmon (Oncorhynchus tshawytscha) daily growth increments and factors influencing their production. Can. J. Fish. aquat. Sci. 39: 1340-1347

Pannella, G. (1980). Growth patterns in fish sagittae. In: Rhoads, D. C., Lutz, R. A. (eds.). Skeletal growth of aquatic organisms: brological records of environmental change. Plenum Press, New York, pp. 519-560

Penny, R. W. Evans, G. T (1985). Growth histories of larval redfish (Sebastes spp) on an offshore Atlantic fishing bank determined by otolith increment analysis. Can. J. Fish. aquat. Sci. 42: 1452-1464

Post. J. R., Prankevicius, A. B. (1987). Size-selective mortality in young-of -the year yellow perch (Perca flavescens): evidence from otolith microstructure Can. J. Fish. aquat. Sci. 44: $1840-1847$

Reznick, D., Lindbeck, E., Bryga, H. (1989). Slower growth results in larger otoliths: an experimental test with guppies (Poecilia reticulata). Can. J. Fish. aquat. Sci. 46: 108-112

Ricker, W. E. (1969). Effects of size-selective mortality and sampling bias on estimates of growth, mortality, production and yield. J. Fish. Res. Bd Can. 26: 479-535

Robinson, S. M. C., Ware, D. M. (1988). Ontogenetic development of growth rates in larval Pacific herring, Clupea harengus pallasi, measured with RNA-DNA ratios in the Strait of Georgia, British Columbia. Can. J. Fish. aquat. Sci. 45: $1422-1429$

Rosenberg, A. A., Haugen, A. S. (1982). Individual growth and size-selective mortality of larval turbot (Scophthalmus maximus) reared in enclosures. Mar Biol. 72: 73-77

Ryland, J. S. (1966). Observations on the development of larvae of the plaice (Pleuronectes platessa), in aquaria. J. Cons. perm. int. Explor Mer 30: 177-195

Secor, D. H., Dean, J. M. (1989). Somatic growth effects on otolith-fish size relationships in young pond-reared striped bass, Morone saxatilis, Walbaum. Can. J. Fish aquat. Sci. 46: $113-121$

Volk, E. C., Wissmar, R. C., Simenstad, C. A., Eggers, D. M., 1984. Relationship between otolith microstructure and the growth of juvenile chum salmon (Oncorhynchus keta) under different prey rations. Can. J. Fish. aquat. Sci. 41. $126-133$

Wilson, K. H., Larkin, P. H. (1982), Relationship between thickness of daily growth increments in sagittae and change in body weight of sockeye salmon (Oncorhynchus nerka) fry. Can. J. Fish. aquat. Sci. 39: 1335-1339

Wright, D. A., Martin, F. D. (1985). The effect of starvation on RNA:DNA ratios and growth of larval striped bass, Morone saxatilis. J. Fish Biol. 27: 479-485

Manuscript first received: April 13, 1989

Revised version accepted: August 9, 1989 